\section{GEOGRAPHY AND THE CAPITAL INVESTMENT COSTS OF URBAN ENERGY INFRASTRUCTURE: THE CASE OF ELECTRICITY AND NATURAL GAS NETWORKS} Müzeyyen Anıl ŞENYEL*, Jean-Michel GULDMANN**
Received: 14.10.2015; Final Text: 12.01.2016

Keywords: Urban energy infrastructure; electricity distribution network; natural gas distribution network; infrastructure costs; economies of scale and density.

\footnotetext{
*Department of City and Regional Planning, Middle East Technical University, Ankara, TURKEY.

**Department of City and Regional Planning, Knowlton School of Architecture, The Ohio State University, Columbus, Ohio, USA.
}

\section{INTRODUCTION}

Urban energy (electricity and natural gas) distribution networks are closely related to the socio-economic and site-specific urban and geographical characteristics of the areas they serve. Overall, these energy systems include generation, transmission and distribution facilities. While generation and production units may be widely dispersed and transmission lines and pipelines may extend over long distances, distribution takes place in urban (built-up) areas, and is thus closely related to urban planning policies and practices. It is difficult and costly to modify these networks after the construction, particularly if underground and therefore their cost structure is a critical component in the decisionmaking of policy makers. If realistic cost functions can be derived for these networks, then infrastructure costs can be forecasted accurately and resources can be allocated in more efficient ways, while providing reliable energy.

Electricity and natural gas distribution costs have been analyzed in the literature, with determinants including input and output variables and a limited number of socio-economic and site-specific variables, such as population density. However, there are complex interactions among energy distribution systems and the characteristics of their service areas. Using more detailed explanatory variables, such as demographic characteristics, land-use patterns, soil conditions and street networks, is expected to provide sophisticated investment costs functions, which can be used for the economic assessment of the existing systems and infrastructure expansion plans. In addition to the cost structure, the presence of economies of scale and density is critical for public policies regarding local competition. More comprehensive cost functions could be used to assess whether there are specific local urban and geographic conditions leading to diseconomies of scale and density; and therefore conducive to competition, with multiple utilities operating at the local level. 
This paper aims to reveal the economic structure of urban energy distribution networks in terms of capital cost models and economies of scale and density analysis. Infrastructure economies are crucial, but usually underestimated in urban planning. The integration of the socio-economic, urban and geographic factors to cost models would not only contribute to the literature, where site-specific variables have often been neglected so far, but also provide guidance for planners and decision makers, who could then better forecast the infrastructure costs of alternative patterns of urban development, and therefore select more economically efficient energy infrastructure networks.

\section{LITERATURE REVIEW}

Studies on the cost structure of electricity and natural gas systems date back to the 1970s. Early research on cost modeling focused on the whole industry; combining the generation, transmission, and distribution components. Research on the monopolistic structure of the industry and scale economies, then, shifted to each component separately. Market characteristics, such as numbers of customers and sales, were considered in all these studies. However, socio-economic, urban, geographic and environmental factors were often neglected in cost function estimations.

\section{Literature on the Cost Structure of Electricity Systems}

Electricity studies include different combinations of the three components: generation, transmission and distribution. Henderson (1985), Roberts (1986), Kaserman and Mayo (1991), Gilsdorf (1995), Thompson (1997), and Kwoka $(1996,2002)$ examine the whole industry, including all three components, and point to the benefits of vertical integration and inseparability of the system. Gilsdorf (1995), in contrast, fails to observe subadditivity conditions for vertically-integrated electricity utilities, and refutes the hypothesis of a natural multiproduct monopoly. More recently, Fraquelli et al. (2005) identify some complementaries among different components, but only slight vertical economies for average-sized firms.

The use of site specific variables is limited in these studies. Primeaux (1975), Weiss (1975), Meyer (1975), and Roberts (1986) do not take any urban, geographic or socio-economic variables into account, but only the inputs and outputs of the industry. Huettner and Landon (1978), Kaserman and Mayo (1991) and Kwoka (1996) use regional dummies; while Nelson and Primeaux (1988) and Thompson (1997) use service territory area, and Gilsdorf (1995), Kwoka (2002) and Fraquelli et al. (2005) consider density variable in addition to market characteristics.

Some studies examine only electricity distribution costs, excluding generation and transmission components. In fact, distribution is the phase most-related to urban-level decision-making, thus, local urban, geographic and socio-economic variables are expected to play important roles in the economic structure of investments. Henderson (1985), Nelson and Primeaux (1988), Nemoto et al. (1993), and Salvanes and Tjotta (1998) analyze the monopolistic structure of the industry, and all studies, except for Nemoto et al. (1993), find evidence of natural monopoly. Meyer (1975), Neuberg (1977), and Clagett (1994) compare the costs and efficiencies of municipal, cooperative and private utilities, while the first two authors favoring municipal firms and the last one cooperative utilities. 
Weiss (1975), Guldmann (1985a, 1988), Salvanes and Tjotta (1994), Filippini (1996, 1998), and Filippini and Wild (2001) observe economies of scale in electricity distribution utilities, while Yatchew (2000) and Filippini $(1996,1998)$ find that economies of scale vary with the size of the firm, and Nemoto et al. (1993) find economies of scale in the short run, but diseconomies in the long-run.

Wells (1977), Huettner and Landon (1978), Guldmann (1985a, 1988), Filippini and Wild (2001), Folloni and Caldera (2001), Kwoka (2002), and Fraquelli et al. (2005) consider the impact on distribution costs of different measures of density, such as number of customers per network unit length, total population over the service area, etc. There are a few studies that include more detailed geographic and environmental variables, such as land use (Guldmann, 1988; Filippini and Wild, 2001; Kwoka, 2002),housing characteristics (Guldmann, 1988), and weather (Jamasb et al. 2012).

\section{Literature on the Cost Structure of Natural Gas Systems}

The development of studies on the cost modeling of natural gas is similar to electricity. Cost structure research started with production, and then shifted to transmission and distribution components. The number of studies, however, is more limited. Guldmann $(1983,1985 \mathrm{~b}$, and 1989) is among the first to econometrically analyze gas distribution costs, with a focus on the multiproduct, multidimensional character of the system. He shows that service densification contributes to economies of scale in a significant way, but market area size expansion contributes only slightly to economies of scale, while Fabbri et al. (2000) provide evidence for constant returns to scale.

Density is the most used site-specific variable in natural gas distribution cost functions. Guldmann (1983, 1985b, and 1989), and Kim and Lee (1995) show that density is negatively related to costs, whereas Fabbri et al. (2000) find that population concentration has a positive effect, which is explained by the diseconomies resulting from urban congestion. Fabbri et al. (2000) also include average altitude, which appears to have a positive effect on costs. Bernard et al. (2002) take regional differences into account and find that the largest and the oldest region has the highest costs. In a recent study, Alaeifar et al. (2014) observe that economies of scale are unexploited for many Swiss gas distribution firms, except for the very large and highdensity ones, and that the optimum firm size can be achieved through firm expansion.

\section{Critical Review of the Literature}

The literature substantially disregards socio-economic, urban and geographic factors of electricity and natural gas distribution costs, while focusing on traditional input (prices) and output (numbers of customers and amount of sales) variables in cost modeling. There are very few studies integrating density or service area into cost estimations. Urban characteristics and urban development patterns do affect energy distribution costs. However, the limited site-specific factors in earlier research cannot help decision makers and planners make inferences about the impacts of urban-related factors on energy investment costs, and accordingly, suggest resource-efficient and economically sound policies. In addition, the literature takes total costs into account, rather than focusing on its capital components, with a common use of the translog functional form in estimations. A detailed analysis of disaggregate cost components, 
together with the exploration of alternative flexible functional forms such as Box-Cox, may contribute to more precise cost estimations.

\section{MODELING APPROACH}

The modeling approach is predicated on the existence of a transformation function that summarizes the feasible substitutions of inputs and outputs, with:

$$
f(\boldsymbol{Q}, L, K, E)=0
$$

where $Q$ is the output vector representing service to different sectors, such as residential, commercial, industrial, public authorities, and street lighting, $L$ is the labor input, $K$ the capital input, and $E$ the energy input which represents energy losses. A vector of site-specific variables, $\mathbf{S H}$, can be added to the transformation function, with:

$$
f(\boldsymbol{Q}, L, K, E, \boldsymbol{S H})=0
$$

Utilities are regulated, with fixed output prices and the requirement to serve all customers in the service territory. Utilities, therefore, minimize their input costs:

$\min C=p_{K} K+p_{L} L+p_{E} E$,

where $p_{K^{\prime}} p_{L^{\prime}}$ and $p_{E}$ are the prices of the capital, labor, and energy inputs, subject to the production constraint represented by Eq. (2).

The cost function derived from the above cost minimization has the general form:

$C(\boldsymbol{Q}, \boldsymbol{P}, \boldsymbol{S H})=P_{K} K^{*}+P_{L} L^{*}+P_{E} E^{*}$

where $\boldsymbol{P}=\left(p_{k^{\prime}} p_{L^{\prime}} p_{E}\right)$ and $K^{*}, L^{*}, E^{*}$ are the optimal input values.

The focus of this research is on the modeling of the capital costs of the distribution system. The capital cost function is:

$C_{K}(\boldsymbol{Q}, \boldsymbol{P}, \boldsymbol{S H})=p_{K} K^{*}(\boldsymbol{Q}, \boldsymbol{P}, \boldsymbol{S H})$

Cost functions are estimated using the numbers of customers and sales in the different sectors (residential, commercial, industrial, and lighting), urban site-specific variables (density, built-up area, street pattern etc), geographic factors (soil type, water table depth, etc.), company specific variables (load factor) and input prices, with:

$C_{i}=\mathrm{F}\left(Q_{i^{\prime}} S I T E, G, C O M P_{i}\right)$

where

$C_{i}=$ Capital investment costs for system $\mathrm{i}$ (gas or electricity),

$Q_{i}=$ Vector of outputs (e.g. residential sales) in system i,

$S I T E=$ Vector of site-specific variables in that specific tax district,

$G=$ Vector of geographic variables,

$\mathrm{COMP}_{i}=$ Vector of company-specific variables for system i.

Because there is no agreed-upon theory regarding the functional form of the capital cost function, both log-log and Box-Cox regressions will be considered. Among the possible alternative functional forms, linear form implies no transformations on any variable, but is ineffective in case of nonlinearity between dependent and independent variables. The double log (log-log) form implies logarithmic transformations on all the variables, and can deal with a specific form of non-linearity. The Box-Cox transformation, 
on the other hand, represents a continuum of functional forms, and the transformation parameters are not pre-determined, that is, they are endogenously determined. When these parameters turn out equal to one, then the transformation is equivalent to the linear model, and when they turn out equal to zero, then it is equivalent to the log-log model. The BoxCox approach is flexible and considers a whole range of functional forms, allowing the data to determine the optimal form.

The log-log regression is defined as:

$\ln y=\alpha_{0}+\alpha_{1} \ln x_{1}+\alpha_{2} \ln x_{2} \ldots+\alpha_{n} \ln x_{n}+u$

The Box-Cox regression is defined as:

$y^{(\theta)}=\alpha_{0}+\alpha_{1} x_{1}^{(\lambda)}+\alpha_{2} x_{2}^{(\lambda)}+\ldots+\alpha_{m} x_{m}^{(\lambda)}+\gamma_{1} z_{1}+\ldots+\gamma_{1} z_{l}+\epsilon$

where the variables $y^{(\theta)}$ and $x_{m}^{(\lambda)}$ are defined by the transformations:

$y^{(\theta)}=\left(Y^{\theta}-1\right) / \theta \quad$ and $x_{m}^{(\lambda)}=\left(X_{m}^{\lambda}-1\right) / \lambda$

The variables $z_{1} \ldots z_{l}$ : are not B-C transformed.

The cost elasticity $\left(\varepsilon_{X_{i}}\right)$ in the log-log form is the coefficient $\alpha_{i}$ of the corresponding independent variable, and is constant. The cost elasticity in the case of the Box-Cox equation, on the other hand, is a function which varies with different input/output values:

$\varepsilon_{X_{i}}=\left(\partial Y / \partial X_{i}\right) *\left(X_{i} / Y\right)=\alpha_{i}\left(X_{i}^{\lambda} / Y^{\theta}\right)$

Both electricity and natural gas utilities are multi-product firms, since they provide different outputs to different customer groups: residential, commercial, industrial, etc. Economies of scale in multi-product firms are measured by ray economies of scale $\left(\varepsilon_{R}\right)$, computed as the sum of the elasticity values for the different outputs. (Note that Baumol at al. define ray economies of scale as the inverse of the sum of the cost elasticites $=$

$\left.1 / \sum \varepsilon_{X_{i}}\right)$

$\varepsilon_{R}=\sum \varepsilon_{X_{i}}$

Generally, economies of scale account for output expansion while holding density constant, that is, while expanding the service area at the same rate as the output, whereas economies of density, $\varepsilon_{D^{\prime}}$ consider output expansion within a fixed area, hence densification. Economies are achieved through densification if $\varepsilon_{D}<1$, with:

$\varepsilon_{D}=\varepsilon_{R}+\varepsilon_{D E N S}$

where $\varepsilon_{D E N S}$ is the density elasticity. Population density is a proxy for network size per customer (e.g., miles of lines per customer), because data on mileages of lines (electricity or gas) are not available at the local level. An increasing population density is therefore taken as equivalent to adding customers (and sales) to a fixed-length network. While the firm has no direct control over population density, it can certainly influence it with policies of network expansion, particularly the differentiated pricing of this expansion.

\section{DATA SOURCES}

The data (company data, census and geographic) used in this study is retrieved from various sources. Company data characterize electricity 
and natural gas distribution companies serving various areas within the state of New York (NYS) in 1980, and include sales, number of customers, distribution plant investment, load factor and input prices. Geographically-detailed investment cost data for 1980 are used because they are available for this year and because more recent data are no longer provided by companies, due to competition and confidentiality concerns. Company data are geographically limited to the territories served. Plant and market data are available for tax districts, which are cities, villages, or towns. However, load factor and input prices are company-wide data, invariant across districts. The use of 1980 data is deemed acceptable because the technologies of distribution for both electricity and natural gas have not changed remarkably, as compared, for instance, with those for telecommunications (land line phones versus cell phones and the Internet). The American Society of Civil Engineers' report on energy infrastructure supports this argument, which states that the electric grid and natural gas pipeline distribution systems are aging, and even some of them dates back to the 1880s (ASCE, Report Card for America's Infrastructure, 2013).

This might change in the future for electricity with a complete conversion to smart grid with distributed generation at the end-user level, which is not the case for current situation. The most significant conversion so far has targeted electric meters, which are being replaced by advanced metering infrastructure (AMI). However electric meters constitute only a limited portion of total distribution system capital costs ( $4 \%$ of the whole system in this study). The U.S. Energy Information Administration indicates that conversion to AMI has been implemented in less than one fourth of the whole U.S., with the conversion to AMI less than 5\% in NYS (EIA, 2012). Aside from meters, distribution systems continue to include, as always, overhead and underground lines, poles, underground conduits, transformers, and substations. In the case of natural gas, distribution system innovations are even more limited, since the network components are still pipelines, service lines, metering and pressure regulating stations.

Census data are derived from the U.S. Census of Population and Housing, which includes detailed information on population and housing, such as population age structure, education, income, housing characteristics and median house values. The same year Census data is used to provide time compatibility. Census data are available at different geographic hierarchical levels. Minor civil division (MCD) level, which comprises cities, villages and towns, provides a perfect match for the tax districts used for company data. Population density variable, derived from Census data, is significant in the electric cost model.

Geographic data include land uses, soil types, topography, and street networks. All these data are processed with Geographic Information Systems (GIS). Land-use data are drawn from the U.S. Geological Survey's (USGS) Geographic Information Retrieval and Analysis System (GIRAS). The major land-use categories are urban or built-up land (residential, commercial, industrial, etc.), agricultural land, forest land, water, wetland, etc. The share of each land use is computed by dividing the total area of each land use by the total area of the tax district, which adds up to one in each tax district. The built-up area variable is significant in the natural gas cost model.

The State Soil Geographic Database of the U.S. Department of Agriculture (STATSGO) is used for retrieving soil data. There are 169 different soil types in NYS. Gas pipes and underground electricity lines are buried; 
hence soil is expected to have an effect on infrastructure costs. Workability, corrosivity, rock depth and water table depth are soil characteristics which may impact investment and maintenance. Workability is defined as a measure of the ease with which a soil is handled and traversed by ordinary construction equipment (Chambers, 1959, 14). For instance, coarse-grained soils are easier to handle in excavation operations than fine-grained soils with high moisture levels. Soil corrosion is the deterioration of metals and other materials brought about by the chemical, mechanical, and biological actions of the soil environment and all underground materials are subject to corrosion. Rock depth and water table depth are related to excavation and drainage. The shares of soil types are calculated by dividing the total area of each soil type by the area of the tax district. Topography data is derived from the USGS digital elevation model (DEM) files, which have 16 slope groups ranging from $0 \%$ and $30 \%$ and over. The definition of steepness varies for different building and construction ordinances. Flat sites $(0 \%-5 \%)$ are easy for transportation and building construction, but they are problematic for drainage. Low slopes (5\% - 10\%) are considered as most suitable for urban development. Steep surfaces $(10 \%-30 \%)$ are hard to work with, and can be dangerous due to slope instability, and extremely steep slopes (30\% and over) are unsuitable for urban development. Among all soil variables, corrosion has a significant effect in the electricity cost model, whereas water table depth does so in both the electricity and natural gas cost models.

Street data are drawn from the Environmental Systems Research Institute (ESRI) street map database. The total street length, the total number of intersections, and the average street segment length (ratio of total street length to total number of intersections) are calculated for each tax district. The data reflect information in 1997. The use of this date is reasonable, because most of the growth has taken place in New York City (NYC), which is not considered in this study. Hence, changes in the street patterns of most places included in this study are most likely negligible. The number of street intersections is used in both electricity and natural gas cost model estimations.

\section{STUDY AREA AND SUMMARY DATA}

Four NYS electricity and gas utilities are considered: Central Hudson Gas and Electricity Company $(\mathrm{CH})$, Long Island Lighting Company (LILCO), Niagara Mohawk Power Corporation (NM), and Orange and Rockland Utilities (OR). The selection considered not only data availability, but also the characteristics of the utilities' service areas. They serve the most populated and urbanized areas in NYS, such as Buffalo, Rochester, Syracuse, Albany, Niagara Falls, Long Beach, and Schenectady, which cover slightly more than half of the total State population after excluding NYC. The utility service areas also cover numerous small and medium sized settlements, besides large urban areas, thus providing variability in geographic unit size. Investment data are available for 1014 tax districts for electricity and 436 tax districts for natural gas. The number of tax districts and average historical value of the distribution plant for both electricity and natural gas are presented in Table 1 . The variations in mean plant size reflect variations in market size and other factors across tax districts.

Detailed historical plant data by vintage year and tax district have been provided by the New York State Division of Equalization and Assessment (NYSDEA). These vintage data have been weighted by the Handy- 


\begin{tabular}{|l|r|r|r|r|}
\hline \multirow{2}{*}{ Company } & \multicolumn{2}{|c|}{ Electricity } & \multicolumn{2}{c|}{ Natural Gas } \\
\cline { 2 - 5 } & Number of Districts & Mean Distribution Plant (\$) & Number of Districts & Mean Distribution Plant (\$) \\
\hline CH & 85 & $1,577,402$ & 37 & 678,255 \\
\hline LILCO & 119 & $4,538,188$ & 113 & 243 \\
\hline NM & 753 & $1,119,132$ & 43 & $1,389,888$ \\
\hline OR & 57 & $1,987,170$ & $1,137,234$ \\
\hline
\end{tabular}

Table 1. Tax Districts with Electricity and Natural Gas Distribution Plants, and Mean Historical Distribution Plant Values, Source: Company Annual Reports - 1980

Figure 1. Geographic Distribution of Districts with Electricity Sales Data Source: NYSDEA and Company Annual Reports
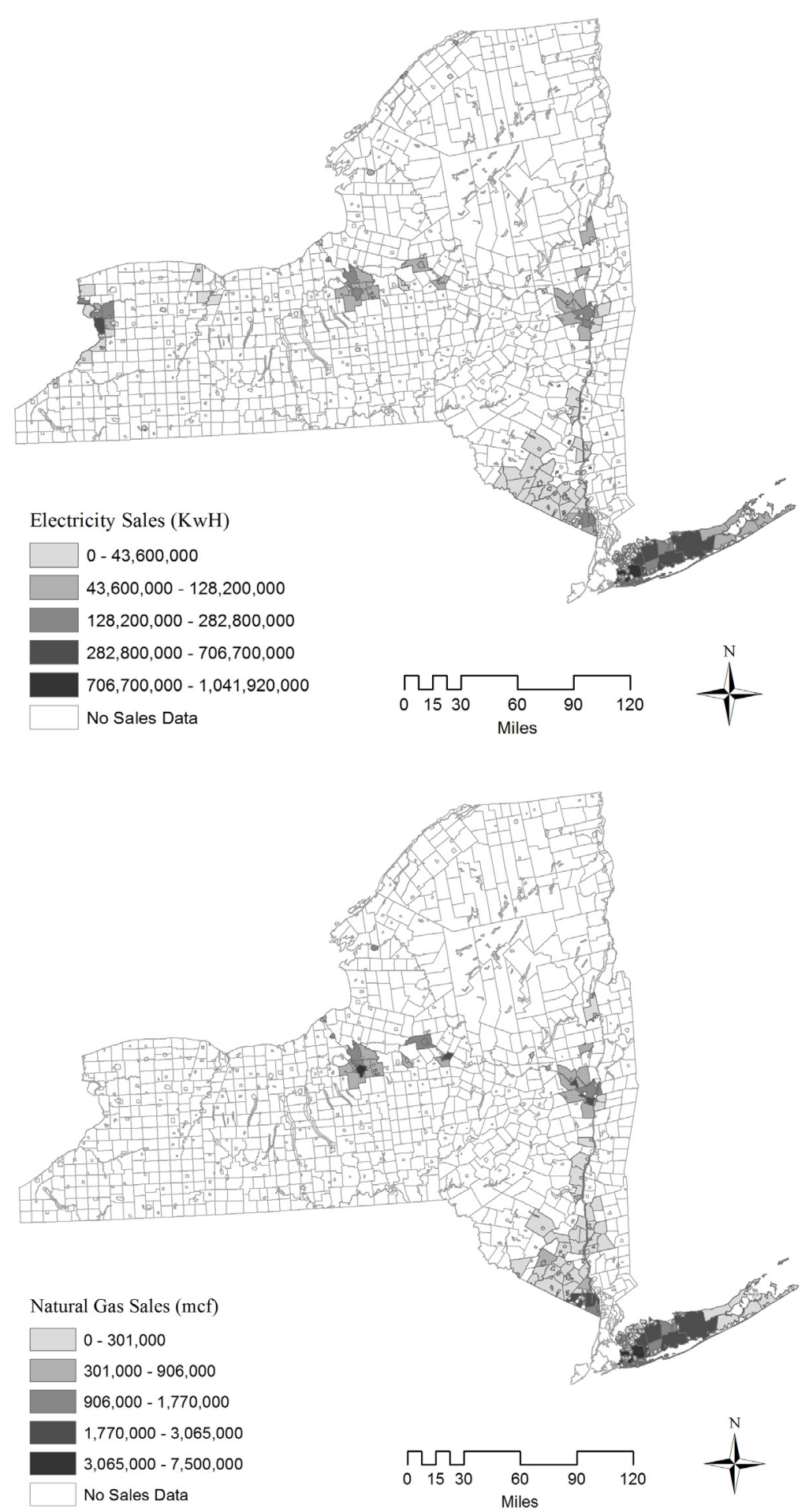

\section{No Sales Data}

Figure 2. Geographic Distribution of Districts with Natural Gas Sales Source: NYSDEA and Company Annual Reports 


\begin{tabular}{|l|r|r|r|r|r|r|}
\hline \multirow{2}{*}{ Company } & \multicolumn{3}{|c|}{ Electricity } & \multicolumn{3}{c|}{ Natural Gas } \\
\cline { 2 - 7 } & Fuel Price \$/kwh & Capital Price \$ & $\begin{array}{l}\text { Wage per } \\
\text { Employee \$ }\end{array}$ & Fuel Price \$/mcf & Capital Price \$ & $\begin{array}{l}\text { Wage per } \\
\text { Employee \$ }\end{array}$ \\
\hline CH & 3.632 & 0.079 & 16,662 & 2.401 & 0.046 & 16,528 \\
\hline LILCO & 3.436 & 0.109 & 17,753 & 2.781 & 0.067 & 20,550 \\
\hline NM & 2.066 & 0.063 & 17,017 & 2.662 & 0.056 & 15,885 \\
\hline OR & 3.433 & 0.084 & 16,005 & 2.435 & 0.095 & 15,336 \\
\hline
\end{tabular}

Table 2. Fuel, Capital and Labor Input Prices for Electricity and Natural Gas Source: Company Annual Reports - 1980
Table 3. Descriptive statistics for the electricity investment cost model $(n=241)$
Whitman index and then summed up into replacement plant values. Market data, however, are available for fewer tax districts: sales and numbers of customers are available for electricity in 241 tax districts, and natural gas in 190 tax districts. The geographic distributions of these districts according to amounts of sales are illustrated in Figures $\mathbf{1}$ and $\mathbf{2}$. Although the tax districts with sales and customers data are limited, they include $52 \%$ of the NYS population (excluding NYC).

Input prices are determined at the company level, and therefore the same price, for a given input, applies to all the districts served by the company. The price of labor is the average wage obtained by dividing the total payroll by the number of employees. Total capital costs are obtained by subtracting payroll and fuel purchases from the total annual revenues, and dividing this residual by the replacement value of the company plant. The input price of electricity is computed by dividing the total costs of fuels used in generation and of electricity purchases by the total amount of electricity sold. The input price of natural gas is similarly computed by dividing the costs of gas purchased by the amount purchased. The resulting prices are presented in Table 2.

\section{RESULTS}

\section{Capital Cost Model for Electricity Distribution}

The electricity distribution plant comprises overhead and underground lines, conduits, services, transformers, poles, and street lighting equipment. Electricity distribution investment costs $\left(C_{E}\right)$ are measured by the distribution plant replacement value, a function of outputs, input prices,

\begin{tabular}{|c|c|c|c|c|}
\hline Variable & Minimum & Maximum & Mean & Std. Deviation \\
\hline $\begin{array}{l}\text { Total electricity investment capital cost } \\
C_{E}(\$)\end{array}$ & 13,968 & $319,335,460$ & $11,246,511$ & $29,383,157$ \\
\hline $\begin{array}{l}\text { Number of residential electricity } \\
\text { customers } N_{\mathrm{RE}}(\#)\end{array}$ & 20 & 144,529 & 6,821 & 16,662 \\
\hline Residential electricity sales $S_{\mathrm{RE}}(\mathrm{kWh})$ & 167,697 & $1,041,919,003$ & $43,503,227$ & $107,788,769$ \\
\hline $\begin{array}{l}\text { Commercial-industrial electricity sales } S_{\mathrm{CIE}} \\
(\mathrm{kWh})\end{array}$ & 1,760 & $2,968,261,212$ & $90,696,852$ & $277,374,196$ \\
\hline Price of fuel $P_{\text {FUEL }}$ (\$) & 2.07 & 3.63 & 3.14 & 0.59 \\
\hline Population density $D E N S_{A}$ (pop./sq.m.) & 14 & 103,058 & 3,517 & 7,202 \\
\hline Number of street intersections INTR (\#) & 13 & 15,114 & 751 & 1,659 \\
\hline Soil corrosivity SOIL ${ }_{\text {CORR }}(\%)$ & 2.78 & 99.9 & 78.14 & 29 \\
\hline Water table depth $W A T_{\text {DEPTH }}$ (feet) & 0.80 & 5.74 & 3.55 & 0.99 \\
\hline
\end{tabular}


and site-specific characteristics. After extensive exploratory analyses, the selected model is:

$C_{E}=\mathrm{F}\left(N_{R E}, S_{R E}, S_{C I E,} P_{\text {FUEL' }}\right.$ DENS $S_{A}$ INTR, SOIL ${ }_{\text {CORR, }}$ WAT $\left.T_{\text {DEPTH }}\right)$

The definitions and descriptive statistics for the variables in Eq. (13) are presented in Table 3.

The regression results are presented in Table 4. The log-likelihood ratio test indicates that the Box-Cox form is superior to the log-log one. Investment costs increase with outputs, fuel price, soil corrosion and the number of intersections, but decrease with population density and water table depth. More intersections increase construction costs because more complex utility

\begin{tabular}{|c|c|c|}
\hline \multirow{2}{*}{ Coefficient } & \multicolumn{2}{|c|}{ Models } \\
\hline & Log-log & $\operatorname{Box}-\operatorname{Cox}(\lambda, \theta)^{\mathrm{a}}$ \\
\hline \multirow[t]{2}{*}{ Constant } & 1.643 & 2.282 \\
\hline & $(2.02)^{\mathrm{b}}$ & $(1.45)$ \\
\hline \multirow[t]{2}{*}{$\mathrm{N}_{\mathrm{RE}}$} & 0.268 & 0.655 \\
\hline & (3.16) & (3.60) \\
\hline \multirow[t]{2}{*}{$\mathrm{S}_{\mathrm{RE}}$} & 0.547 & 0.424 \\
\hline & $(7.36)$ & (5.95) \\
\hline \multirow[t]{2}{*}{$\mathrm{S}_{\mathrm{CIE}}$} & 0.117 & 0.121 \\
\hline & $(4.61)$ & $(4.50)$ \\
\hline \multirow[t]{2}{*}{$P_{\text {FUEL }}$} & 0.358 & 1.312 \\
\hline & (1.98) & $(2.00)$ \\
\hline \multirow{2}{*}{ DENS $_{A}$} & -0.162 & -0.307 \\
\hline & $(-6.09)$ & $(-5.38)$ \\
\hline \multirow[t]{2}{*}{ INTR } & 0.099 & 0.272 \\
\hline & (2.07) & (2.23) \\
\hline \multirow[t]{2}{*}{$\mathrm{SOIL}_{\text {CORR }}$} & 0.220 & 0.633 \\
\hline & $(3.02)$ & (3.23) \\
\hline \multirow[t]{2}{*}{ WAT $_{\text {DEPTH }}$} & -0.204 & -0.681 \\
\hline & $(-1.81)$ & $(-1.76)$ \\
\hline \multirow[t]{2}{*}{$\lambda$} & & 0.087 \\
\hline & & $(0.004)^{c}$ \\
\hline \multirow[t]{2}{*}{$\theta$} & & 0.09 \\
\hline & & $(0.012)^{c}$ \\
\hline $\mathrm{R}^{2}$ & 0.927 & 0.933 \\
\hline Log-likelihood & -3741.02 & -3736.37 \\
\hline $\mathrm{HO}: \theta=\lambda=0$ & Chi-sq=8.49d, & $p>$ Chi-sq $=0.004$ \\
\hline $\mathrm{HO}: \theta=\lambda=1$, & Chi-sq=741.03, & $p>$ Chi-sq $=0.000$ \\
\hline
\end{tabular}


Table 5. Electricity Distribution Cost Elasticities at the Sample Mean

\begin{tabular}{lr}
\hline Elasticity & Sample Mean \\
\hline$\varepsilon_{\text {NRE }}$ & 0.327 \\
$\varepsilon_{\text {SRE }}$ & 0.451 \\
$\varepsilon_{\text {SCIE }}$ & 0.137 \\
$\varepsilon_{\text {PFUEL }}$ & 0.337 \\
$\varepsilon_{\text {DENSA }}$ & -0.145 \\
$\varepsilon_{\text {INTR }}$ & 0.112 \\
$\varepsilon_{\text {SOILORR }}$ & 0.215 \\
$\varepsilon_{\text {WATDEPTH }}$ & -0.177 \\
\hline
\end{tabular}

layouts are required. Likewise, a higher corrosivity increases maintenance and replacement cost of underground components. The negative coefficient of the density variable can be explained by capital savings in dense areas, with shorter distribution lines as compared to low-density areas. An increasing water table depth decreases costs, because less drainage is needed. The higher the fuel price, the higher the need to reduce electricity losses through additional investments. Note that the prices of capital and labor are not included in the equation, because they were insignificant, possibly because the values for the four companies do not display enough variability.

Cost elasticities at the sample mean (Table 5) show that residential sales have the highest elasticity, $\varepsilon_{S R E}$. A $1 \%$ increase in residential sales increases costs by $0.45 \%$. The effects of residential customers $\left(\varepsilon_{\text {SNRE }}\right)$ and fuel price $\left(\varepsilon_{\text {PFUEL }}\right)$ are relatively close, with a $1 \%$ increase in any of these variables resulting in around $0.3 \%$ increase in costs. A $1 \%$ increase in soil corrosivity $\left(\varepsilon_{\text {SOILCORR }}\right)$ increases costs by $0.2 \%$. The effects of commercial-industrial sales $\left(\varepsilon_{S C I E}\right)$, area density $\left(\varepsilon_{D E N S A}\right)$, number of intersections $\left(\varepsilon_{\text {INTR }}\right)$, and water table depth $\left(\varepsilon_{\text {WATDEPTH }}\right)$ have smaller impacts, with a $1 \%$ increase in any of these variables resulting in $0.1 \%-0.2 \%$ changes in costs.

An electricity distribution utility may be considered as a multi-product firm, providing service to various customers (residential, commercialindustrial, and lighting) with different product requirements. Ray economies of scale (Baumol et al., 1982) are measured by:

$\varepsilon_{C E}=\varepsilon_{\text {NRE }}+\varepsilon_{S R E}+\varepsilon_{S C I E}$

Using the Box-Cox function in Table 4, Eq. (14) becomes:

$\varepsilon_{C E}=\left[0.655 * N_{R E}^{0.087}+0.424 * S_{R E}^{0.087}+0.121 * S_{C I E}^{0.087}\right] / C_{E}^{0.09}$

Ray economies of scale are calculated at the sample mean, as well as for each individual observation (tax district). The value of 0.915 for $\varepsilon_{C E}$ at the sample mean points to slight economies of scale achieved through system expansion at constant density. The lowest, highest, and average values of economies of scale for individual observations are $0.842,0.990$, and 0.912 respectively, indicating slight economies of scale in all districts.

Varying output levels are likely to affect economies of scale. The outputs are the numbers of residential customers, residential sales $(\mathrm{kwh})$, and commercial-industrial sales $(\mathrm{kwh})$. A parameter $k$ is used to represent residential and commercial-industrial sales, which are assumed to expand at the same rate, while keeping residential customer size $Z_{R E}$ (ratio of residential sales to number of residential customers) constant. 
Figure 3. Economies of Scale for Electricity Distribution, $\varepsilon_{\mathrm{CE}}$ versus Output Parameter $k$.

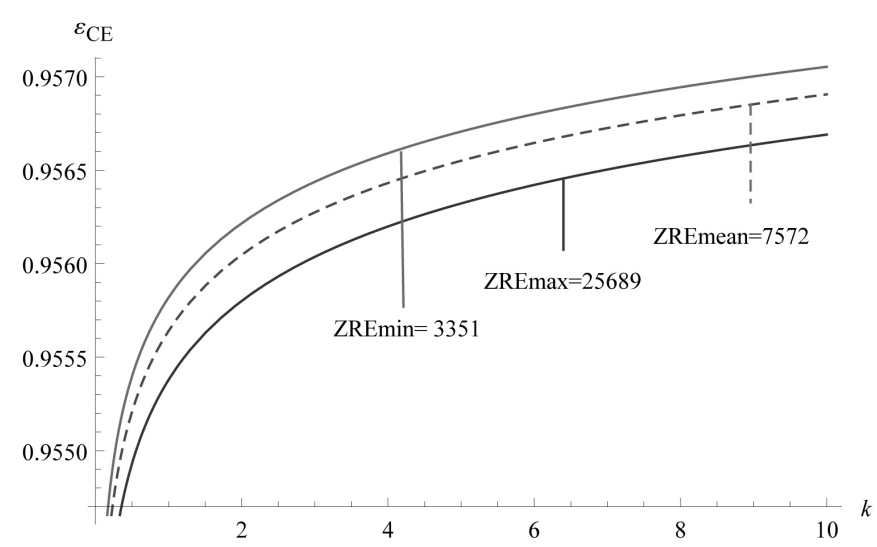

Therefore, the number of residential customers also expands at the same rate. Residential sales, commercial-industrial sales, and the number of residential customers are related to their mean sample value, with: (1) $S_{R E}=k^{*} S_{\text {REmean }}=k^{*} 43,503,227$; (2) $S_{C I E}=k^{*} S_{\text {CIEmean }}=k^{*} 90,696,852$; and (3) $N_{R E}=S_{R E} /$ $Z_{R E}=k^{*} 43,503,227 / Z_{R E}$. Different output levels $k$ are considered for the minimum, mean, and maximum values of $Z_{R E}$. Figure 3 displays the variations of economies of scale, $\varepsilon_{C E}$ with $k$, for $Z_{\text {REmin }}(3351), Z_{\text {REmean }}(7572)$, and $Z_{\text {REmax }}(25689)$.

Whatever $Z_{R E^{\prime}}$ ray economies of scale decline ( $\varepsilon_{C E}$ increases) with an increasing output $(k)$, suggesting that larger markets (i.e. larger cities) provide less opportunities for economies of scale. For a given market size ( $k$ fixed), the larger $Z_{R E}$ the larger the economies of scale. When $Z_{R E}$ increases in a given market, the number of residential customers decreases. It is more expensive to serve areas where the number of customers is at a minimum, and therefore there are more opportunities to decrease costs by hooking up new customers and expanding sales. When the outputs increase ten-fold, $\varepsilon_{C E}$ becomes very close to 0.959 for $Z_{R E m i n}$. The elasticity curve of $Z_{R E m i n}$ has a horizontal asymptote, at $\varepsilon_{C E}=0.963$, meaning that economies of scale do not exceed 0.963 . Thus, diseconomies of scale have not been observed in this sample.

Changes in the economies of scale curves are assessed for the minimum, mean, and maximum levels of the following variables: fuel price, population density, number of intersections, soil corrosivity, and water table depth (Figure 4). The mean customer size, $Z_{\text {REmean }}=7,572$ is utilized in all cases. The value of $\varepsilon_{C E}$ never exceeds 1 . Economies of scale vary from 0.90 to 0.94 when considering the minimum and maximum fuel prices. The $\varepsilon_{C E}$ curve is almost horizontal for the maximum population density, which suggests that, at high densities, cost elasticity is almost independent of the output, with an approximate value of 0.97 . The minimum density yields much higher economies of scale, with $\varepsilon_{C E}$ ranging from 0.80 to 0.89 . Economies of scale vary from 0.91 to 0.97 when considering the minimum and maximum numbers of street intersections. Soil corrosivity has an outlier minimum value of 2.78 percent, which leads to an almost horizontal curve at $\varepsilon_{C E}=0.97$. At the mean and maximum corrosivity levels, the elasticity curves are very close to each other, between 0.90 and 0.93 . When the water table depth is at its maximum value, economies of scale are lowest, with $\varepsilon_{C E}=0.935$. 

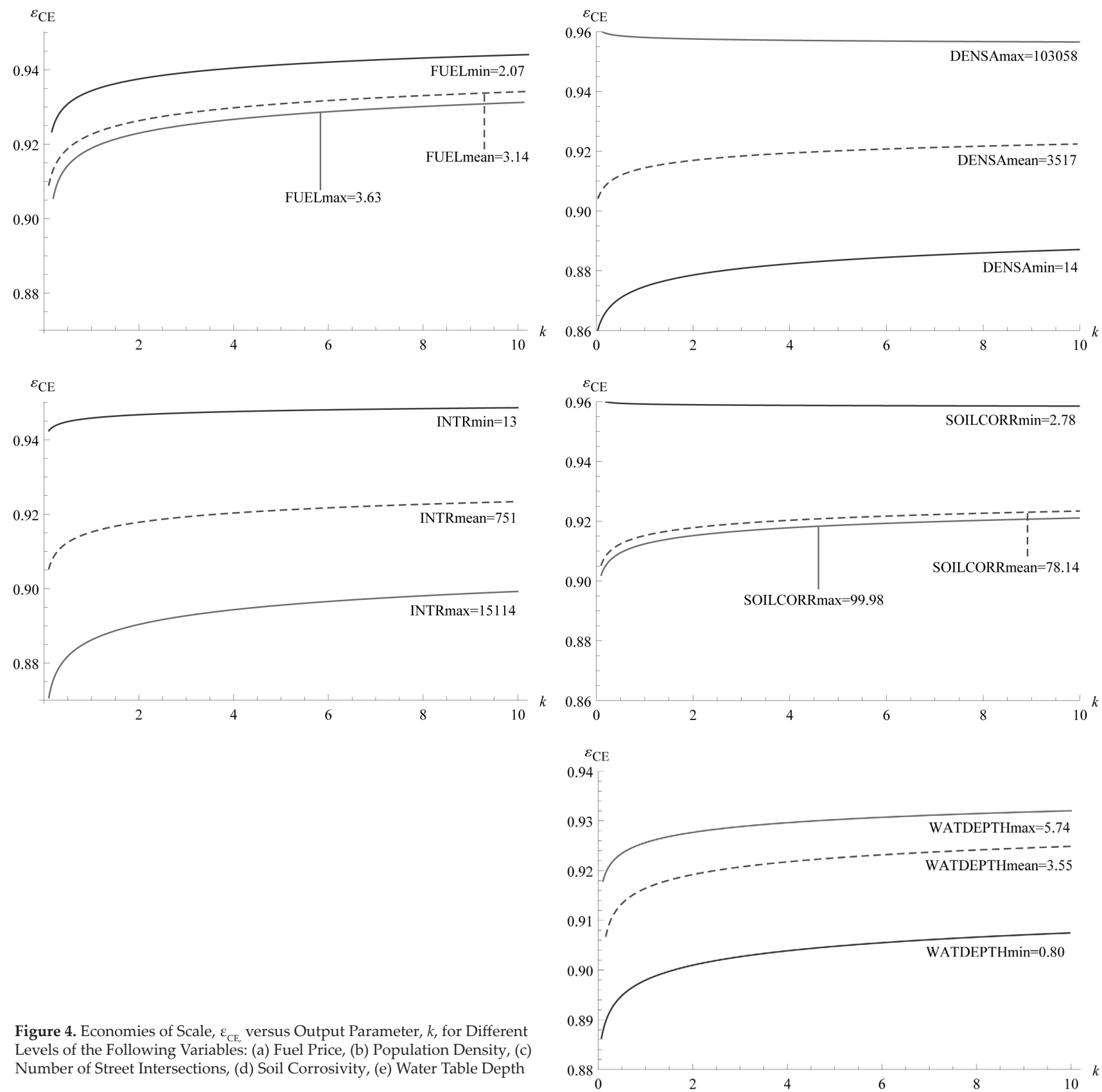

Figure 4. Economies of Scale, $\varepsilon_{\text {e }}$ versus Output Parameter, $k$, for Differen Levels of the Following Variables: (a) Fuel Price, (b) Population Density, (c) Number of Street Intersections, (d) Soil Corrosivity, (e) Water Table Depth

The economies of density, $\varepsilon_{D E^{\prime}}$ represent the effects of both service densification and expansion, with:

$\varepsilon_{D E}=\varepsilon_{C E}+\varepsilon_{D E N S A}$

Using the Box-Cox function in Table 4, Equation (16) becomes:

$$
\varepsilon_{D E}=\left[0.655 * N_{R E}^{0.087}+0.424 * S_{R E}^{0.087}+0.121 * S_{C I E}^{0.087}-0.307 D E N S_{A}^{0.087}\right] / C_{E}^{0.09}
$$

The value of $\varepsilon_{D E}$ at the sample mean is 0.771 , pointing to higher economies of density, which are also calculated for each individual tax district, with minimum, maximum and average values at $0.7,0.812$, and 0.759 . 
Figure 5. Economies of Density for Electricity Distribution, $\varepsilon_{D E}$, versus Output Parameter $k$.

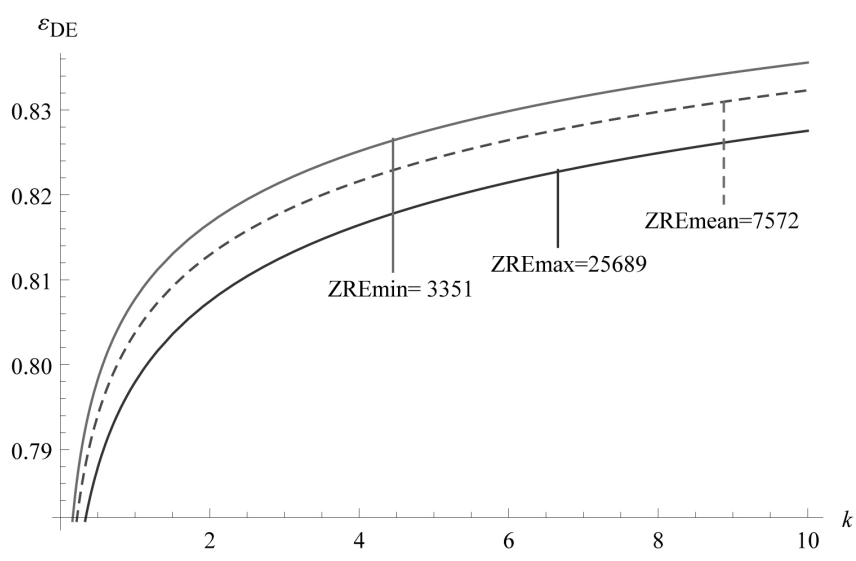

The variations of $\varepsilon_{D E}$ with the output parameter $k$ are analyzed for the minimum, mean, and maximum values of customer size, $Z_{R E}$ (Figure 5). For any value of $Z_{R E^{\prime}}$ economies of density decline ( $\varepsilon_{D E}$ increases) with output. For a given market size $k$, the larger $Z_{R E}$ the larger $\varepsilon_{D E}$. Areas with a smaller number of customers probably provide more opportunities for savings by hooking up new infill customers. The $\varepsilon_{D E}$ curve for $Z_{R E m i n}$ has a horizontal asymptote at $\varepsilon_{D E}=0.877$, which can be compared to the limit value of 0.963 for $\varepsilon_{C E}$.

Changes in economies of density are assessed for variations in the other variables: fuel price, population density, number of street intersections, soil corrosivity, and water table depth. These changes are depicted in Figure 6. Higher fuel prices lead to higher economies of density (lower curve). Low-density areas have the highest economies of density, because these areas are very expensive to serve, and therefore increasing their densities by adding customers through "infill" is likely to significantly reduce unit costs. Conversely, higher densities decrease costs, but provide fewer opportunities for larger economies of scale. Areas with more street intersections have stronger economies of density: a larger number of intersections provide more flexibility in extending the network to connect new customers. Maximum soil corrosivity leads to the largest economies of density: expansion of lines through densification require shorter lines, less exposed to corrosion, hence the higher economies. A deeper water table leads to fewer operational costs, which may limit the potential gains through expansion with densification.

\section{Capital Cost Model for Natural Gas Distribution}

The natural gas distribution plant comprises mains, services, measurement and regulation stations, and structure and improvements. Natural gas distribution investment costs $\left(C_{G}\right)$ measured by the distribution plant replacement value, are a function of outputs, input prices, and site-specific characteristics. After extensive exploratory analyses, the selected model is:

$C_{G}=F\left(N_{R G}, S_{R G}, S_{C I G,} P_{F U E L^{\prime}} A_{B L T P,}\right.$ INTR, WAT $\left.T_{D E P T H}\right)$

The definitions and descriptive statistics for the variables in Eq. (18) are presented in Table 6.

The regression results are presented in Table 7 . The log-likelihood ratio test indicates that the Box-Cox form is superior to the log-log one. The urbanrelated variables, built-up area and number of intersections, have positive effects on costs, as expected. Intersections make construction work more 

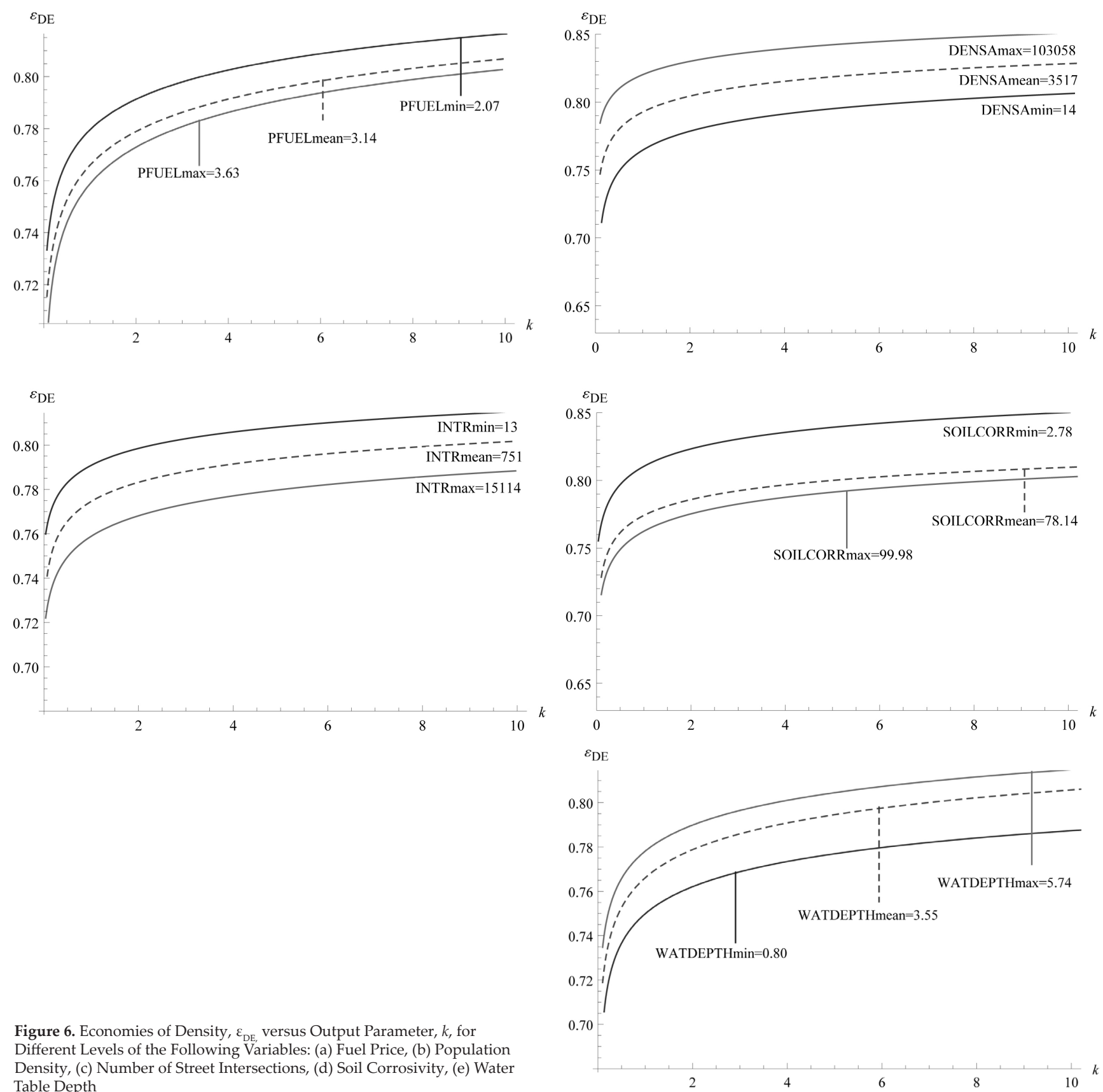

Figure 6. Economies of Density, $\varepsilon$ versus Output Parameter, $k$, for Different Levels of the Following Variables: (a) Fuel Price, (b) Population Density, (c) Number of Street Intersections, (d) Soil Corrosivity, (e) Water Table Depth

complex and necessitate more capital. A deeper water table (as in the case of electricity) decreases operational costs due to less need for drainage, and therefore has a negative effect on costs. An increase in fuel price increase costs, as investments are made to stem gas losses. The higher the price of natural gas, the stronger the need to reduce gas losses through additional investments. Prices of capital and labor are not included in the equation, as in the case of the electricity model, because they were insignificant, most likely because of a lack of sufficient variability across the four companies.

Cost elasticities at the sample mean are presented in Table 8. Fuel price has the highest elasticity $\left(\varepsilon_{\text {PFUEL }}\right)$ : when it increases by $1 \%$, cost increases 


\begin{tabular}{|c|c|c|c|c|}
\hline Variable & Minimum & Maximum & Mean & Std. Deviation \\
\hline $\begin{array}{l}\text { Total natural gas } \\
\text { investment capital cost } \\
C_{G}(\$)\end{array}$ & 34,874 & $108,274,446$ & $7,656,032$ & $14,548,161$ \\
\hline $\begin{array}{l}\text { Number of residential } \\
\text { natural gas customers } \\
N_{\mathrm{RG}}(\#)\end{array}$ & 4 & 71,583 & 4,471 & 8,515 \\
\hline $\begin{array}{l}\text { Residential natural gas } \\
\text { sales } S_{\mathrm{RG}}(\mathrm{kWh})\end{array}$ & 8 & $7,493,316$ & 411,433 & 859,346 \\
\hline $\begin{array}{l}\text { Commercial-industrial } \\
\text { natural gas sales } \quad S_{\mathrm{CIG}} \\
\text { (mcf) }\end{array}$ & 4 & $5,541,700$ & 311,081 & 667,499 \\
\hline Price of fuel $P_{\text {FUEL }}(\$)$ & 2.4 & 2.78 & 2.64 & 0.16 \\
\hline $\begin{array}{l}\text { Built-up area } A_{\text {BLTP }} \text { (sq } \\
\text { miles) }\end{array}$ & 0.04 & 134 & 6.51 & 14.45 \\
\hline $\begin{array}{l}\text { Number of street } \\
\text { intersection s INTR (\#) }\end{array}$ & 13 & 15,114 & 851 & 1,821 \\
\hline $\begin{array}{l}\text { Water table depth } \\
\text { WAT } T_{\text {DEPTH }} \text { (feet) }\end{array}$ & 0.8 & 5.74 & 3.62 & 0.86 \\
\hline
\end{tabular}

by $1.85 \%$. Residential sales have the second highest elasticity, with $\varepsilon_{S R G=}$ 0.46 . Water table depth has also a relatively high elasticity $(0.34)$, but with a negative sign. The elasticities of the number of residential customers $\left(\varepsilon_{\text {NRG }}\right.$ $=0.154)$, commercial-industrial sales $\left(\varepsilon_{S C I G}=0.067\right)$, built-up area $\left(\varepsilon_{A B L T P}=\right.$ $0.110)$, and the number of intersections $\left(\varepsilon_{\text {INTR }}=0.187\right)$ are close to each other.

Ray economies of scale are measured by the effect of increases in sales and numbers of customers at constant density. The built-up area variable captures area expansion, and increasing it keeps density constant. It follows that:

$\varepsilon_{C G}=\varepsilon_{N R G}+\varepsilon_{S R G}+\varepsilon_{S C I G}+\varepsilon_{A B L T P}$

Using the Box-Cox function in Table 7, Eq. (19) becomes:

$\varepsilon_{C G}=\left[0.916 * N_{R G}^{0.172}+1.256 * S_{R G}^{0.172}+0.192 * S_{C I G}^{0.172}+2.025 A_{B L T P}^{0.172}\right] / C_{E}^{0.203}$

$\varepsilon_{C G}$ has a value of 0.792 at the sample mean, pointing to economies of scale. The lowest, highest, and average values of $\varepsilon_{C G}$ computed over all individual tax districts (190) are 0.699, 0.998, and 0.818, respectively. Economies of scale get very close to but never exceed 1 .

The variations in economies of scale with output are analyzed in the same way as for electricity, using the minimum, $Z_{R G \min { }^{\prime}}$ mean, $Z_{R G m e a n}$ and maximum, $Z_{R G \max }$, values of the average residential customer size. The output variables are defined as follows: (1) $S_{R G}=k^{*} S_{R G \text { mean }}$ $=k^{*} 411,433$; (2) $S_{C I G}=k^{*} S_{\text {CIGmean }}=k^{*} 311,081$; and (3) $N_{R G}=S_{R G} / Z_{R G}=k^{*} 411,433 /$ $Z_{R G}$. The resulting $\varepsilon_{C G}$ curves are presented in Figure 7. Whatever $Z_{R G^{\prime}}$ economies of scale decline ( $\varepsilon_{C G}$ increases) with an increasing output, as in the case of electricity. Larger markets provide less opportunities for economies of scale. If market size $(k)$ is fixed, the smaller $Z_{R G}$ the smaller the economies of scale. Increasing values of $Z_{R G}$ imply smaller numbers of residential customers. Areas with less customers are more 


\begin{tabular}{lrr}
\hline \multirow{2}{*}{ Coefficient } & \multicolumn{2}{c}{ Models } \\
\cline { 2 - 3 } Constant & Log-log & Box-Cox $(\lambda, \theta)^{\mathrm{a}}$ \\
& 4.915 & -21.761 \\
$\mathrm{~N}_{\mathrm{RG}}$ & $(6.68)^{\mathrm{b}}$ & $(-2.12)$ \\
& 0.195 & 0.916 \\
$\mathrm{~S}_{\mathrm{RG}}$ & $(3.95)$ & $(3.77)$ \\
& 0.36 & 1.256 \\
$\mathrm{~S}_{\text {CIG }}$ & $(8.46)$ & $(11.34)$ \\
& 0.085 & 0.192 \\
$\mathrm{P}_{\text {FUEL }}$ & $(3.32)$ & $(2.36)$ \\
& 2.511 & 39.715 \\
$\mathrm{~A}_{\text {BLTP }}$ & $(4.46)$ & $(4.75)$ \\
& 0.132 & 2.025 \\
INTR $^{*}$ & $(2.02)$ & $(2.06)$ \\
& 0.219 & 1.478 \\
WAT $_{\text {DEPTH }}$ & $(2.78)$ & $(2.96)$ \\
& -0.4 & -6.972 \\
& $(-3.11)$ & $(-3.7)$
\end{tabular}

$\lambda$

Table 7. Total Natural Gas Distribution Cost Function Estimates ( $\mathrm{n}=190)$

a Selected model

${ }^{\mathrm{b}} \mathrm{t}$-statistics in parentheses

${ }^{\mathrm{c}} \mathrm{p}$-value

${ }^{\mathrm{a}}$ Log-likelihood test result

Table 8. Natural Gas Distribution Cost Elasticities at the Sample Mean
Log-likelihood

$-2907.2$

$-2886.53$

HO: $\theta=\lambda=0^{d}$,

Chi-sq=41.34,

p $>$ Chi-sq $=0.000$

HO: $\theta=\lambda=1$,

Chi-sq=437.32,

\begin{tabular}{lr}
\hline Elasticity & Sample Mean \\
\hline$\varepsilon_{\mathrm{NRG}}$ & 0.154 \\
$\varepsilon_{\mathrm{SRG}}$ & 0.461 \\
$\varepsilon_{\mathrm{SCIG}}$ & 0.067 \\
$\varepsilon_{\mathrm{PFUEL}}$ & 1.853 \\
$\varepsilon_{\mathrm{ABLTP}}$ & 0.110 \\
$\varepsilon_{\mathrm{INTR}}$ & 0.187 \\
$\varepsilon_{\text {WATDEPTH }}$ & -0.344 \\
\hline
\end{tabular}

expensive to serve, hence provide more opportunities for cost reductions with service expansion. The limit value of $\varepsilon_{C G}$ is 0.85 with $Z_{R G m i n}=3$. Thus, there are always economies of scale for gas distribution for any customer size value when all the other variables are at their sample mean values. 
Figure 7. Economies of Scale for Gas Distribution, $\varepsilon_{\mathrm{CG}}$, versus Output Parameter $k$.

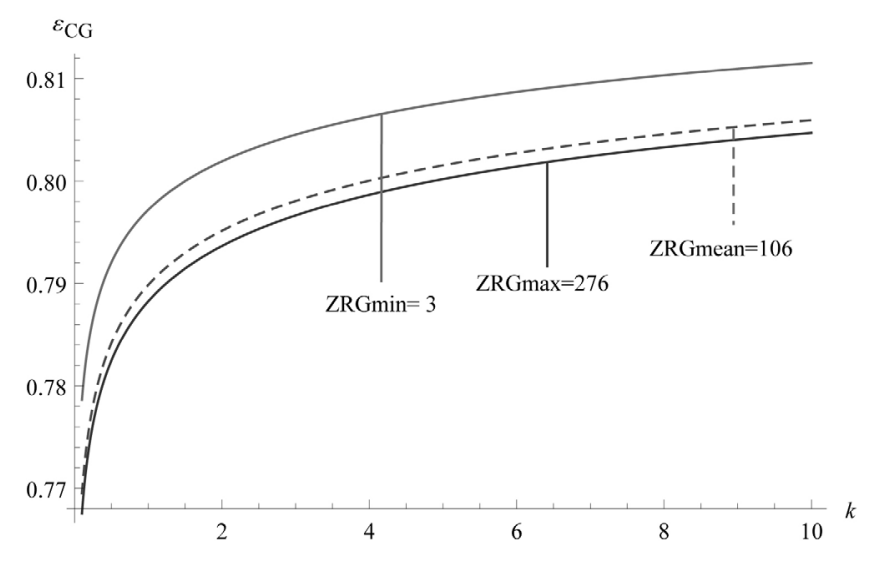

Changes in economies of scale are analyzed for the minimum, mean, and maximum levels of fuel price, built-up area, number of intersections, and water table depth, at the mean residential customer size level $Z_{R G}=106.2$ (Figure 8). In all cases, $\varepsilon_{C G} \in[0.70-0.85]$. The curves for built-up area and number of intersections are similar, but with different ranges. Varying the built-up area yields $\varepsilon_{C G}$ values ranging between 0.70 and 0.85 , while varying the number of street intersections yields $\varepsilon_{C G} \in[0.60-0.90]$. The minimum built-up area and the minimum number of street intersections yield the lowest economies of scales (highest curves). Expanding output while simultaneously expanding territory under such conditions may be expensive and provides little room for economies of scale. The water table
Figure 8. Economies of Scale, $\varepsilon_{\mathrm{CG}}$, versus Output Parameter $k$, for Different Levels of the Following Variables: (a) Fuel Price, (b) Built-up Area, (c) Number of Street Intersections, (d) Water Table Depth.
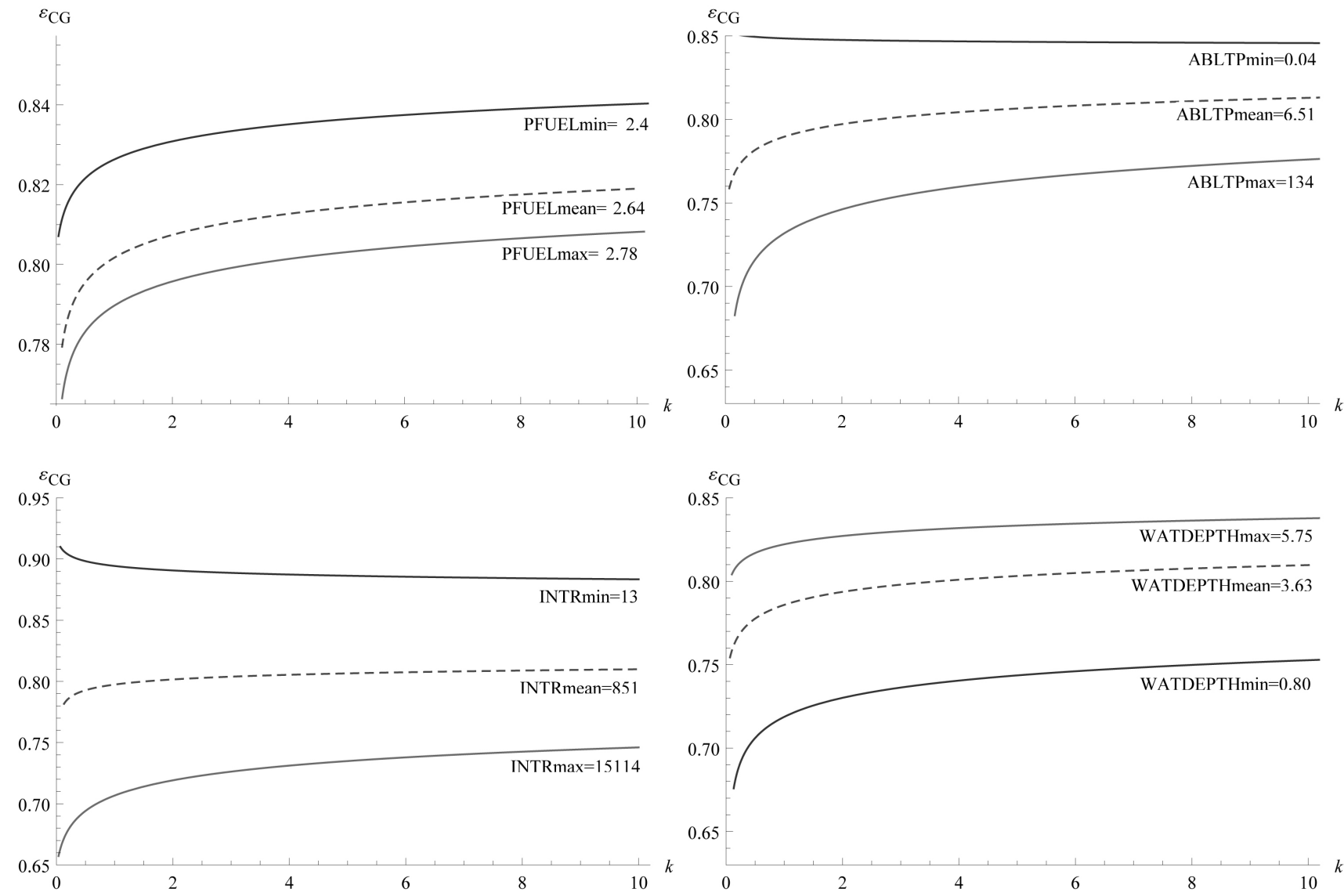
depth has an outlier maximum value of 5.74. A water table far from the surface leads to lower costs, and it becomes hard to decrease costs further, whereas in areas with a water table close to the surface costs are high, thus cost reductions are more achievable. The minimum fuel price yields a lower level of $\varepsilon_{C G^{\prime}}$ around 0.84 .

The economies of density, $\varepsilon_{D G^{\prime}}$ represent the effects of both service densification and expansion. The elasticity of built-up area is removed from Eq. (21) to capture the effect of densification, with:

$\varepsilon_{D G}=\varepsilon_{C G}-\varepsilon_{A B L T P}=\varepsilon_{N R G}+\varepsilon_{S R G}+\varepsilon_{S C I G}$

Using the Box-Cox function in Table 7, Eq. (21) becomes:

$\varepsilon_{D G}=\left[0.916 * N_{R G}^{0.172}+1.256 * S_{R G}^{0.172}+0.192 * S_{C I G}^{0.172}\right] / C_{E}^{0.203}$

The value of $\varepsilon_{D G}$ at the sample mean is 0.682 . Economies of density are also calculated for each tax district, with minimum, maximum and average values at $0.496,0.930$, and 0.697 , respectively. Economies of density never exceed 1.

The variations of $\varepsilon_{D G}$ with $k$ are analyzed for the minimum, mean and maximum values of residential customer size, $Z_{R G}$ (Figure 9). The maximum and mean average customer sizes yield economies of density levels very close to each other. Economies of density are greater for higher customer sizes. In a given market $k$, increasing $Z_{R G}$ means decreasing the number of customers, which probably provides savings through easier hook-up of new infill customers.

The economies of density for different levels of the other variables are presented in Figure 10. In all cases, the mean customer size, $Z_{R G m e a n}$ is used. Larger built-up areas benefit more from densification than smaller ones, possibly because of better hook-up opportunities for infill customers. The rankings of the elasticity curves for fuel price, number of street intersections, and water table depth are similar to those observed in the case of expansion without densification, and the same interpretations of the results apply here.

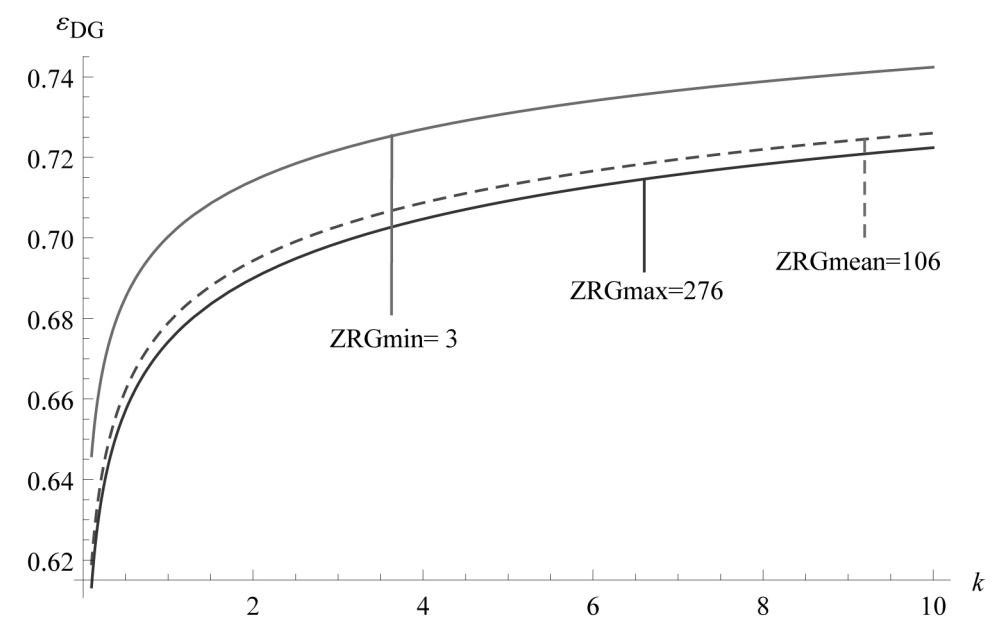



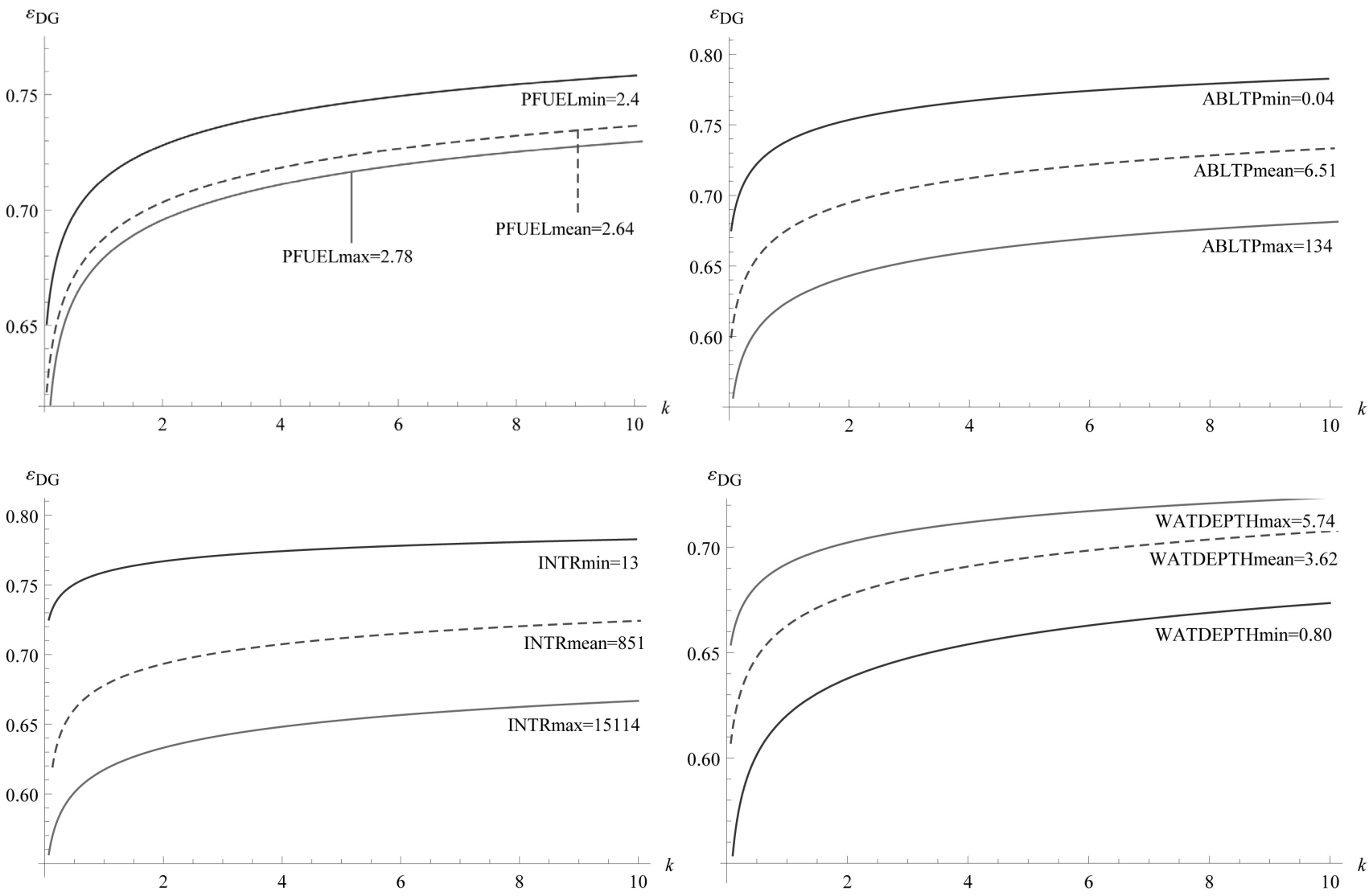

Figure 10. Economies of Density, $\varepsilon_{\mathrm{DG}}$, versus Output Parameter $k$, for Different Levels of the Following Variables: (a) Fuel Price, (b) Built-up Area, (c) Number of Street Intersections, (d) Water Table Depth.

\section{CONCLUSIONS}

This research has demonstrated that the capital costs of electricity and natural gas distribution depend on site-specific and socio-economic characteristics, as well as on output values and input prices, and the Box-Cox functional form is superior to the log-log and linear forms in all cases. The number of residential customers, residential sales, commercialindustrial sales, and fuel prices are significant for both electricity and natural gas capital costs, and all these variables have positive coefficients, which is consistent with earlier research.

The number of street intersections and the depth of the water table are the site-specific urban and geographic related variables that are also common to both models. The number of street intersections has a positive coefficient, as more intersections are likely to complicate network construction. The depth of the water table, on the other hand, is inversely related to costs, since a decreasing depth increases the need for drainage, and hence increases costs.

The number of street intersections and the depth of the water table are the site-specific urban and geographic variables that are also common to both models. The number of street intersections has a positive coefficient, as more intersections are likely to complicate network construction. The depth of the water table, on the other hand, is inversely related to costs, since a decreasing depth increases the need for drainage, and hence costs. Population density and soil corrosivity are statistically significant only in electricity distribution costs. Population density has a negative effect, since low-density areas with larger plots require longer conductor lines and 
more associated equipment than high-density areas. Higher soil corrosivity requires special materials and use of conduits to protect lines and equipment, thus, leading to higher costs. The built-up area has a positive effect on natural gas capital investment only, meaning that for a given market, the larger the territory the lower the density, hence the higher the costs. This variable can be considered as a proxy for density.

Very slight economies of scale are observed for electricity distribution in the case of market expansion at constant density. However, stronger economies are achieved with market densification. Changes in economies of scale and density have been assessed for different levels of market size, customer size, fuel price, and site-specific variables. Higher fuel prices, lower population density, higher soil corrosivity, lower water table depth and more street intersections lead to higher economies of scale and higher economies of density in electricity distribution. When site specific conditions are more favorable (for instance low corrosivity, deep water table, and fewer street intersections), costs are already low, and there is less room for further economic gains from output increase or densification.

Stronger economies of scale and economies of density are observed in the case of natural gas distribution. Higher fuel prices, larger built-up areas, lower water table depth, and more street intersections allow for more cost reductions, and also higher levels of economies of density in natural gas distribution. In case of less favorable site-specific conditions (for instance a low water table depth and more street intersections) there is more room for gains from output increase or densifications.

To sum up, site specific urban and geographical factors should be considered in energy distribution investments. Dispersed and low density urban development tends to increase energy infrastructure investment costs. Moreover, soil conditions should be taken into account such that areas with lower water table depth and corrosive lands add more costs to construction. Finally, diseconomies of scale and density have not been observed in any output combinations at different levels of variables in electricity and natural gas, implying that competition is not an economically reasonable strategy for both sectors. Electricity and natural gas urban distribution networks always retain the characteristics of natural monopolies that should be regulated by public authorities.

\section{List of Symbols and Abbreviations}

$\varepsilon$ : Elasticity

$A_{B L T P}$ : Built-up area

Box-Cox: Transformation operation developed by George Box and

David Cox to enable to define regression parameter(s) for both dependent variable and independent variables

$C_{E}$ : Capital cost of electricity

$C_{G}$ : Capital cost of natural gas

$\mathrm{CH}$ : Central Hudson Gas and Electricity Company

$C_{K}$ : Capital investment cost

$\mathrm{COMP}_{i}=$ Vector of company-specific variables for system $\mathrm{i}$

DEM: Digital elevation models

$D E N S_{A}$ : Population density of the tax district

E: Energy input

Eq.: Equation 
ESRI: Environmental Systems Research Institute

$f$ : function

$G=$ Vector of geographic variables,

GIRAS: Geographic Information Retrieval and Analysis System

GIS: Geographic Information Systems

INTR: Number of street intersections

$K^{*}, L^{*}, E^{*}$ : Optimal input values

K: Capital input

k: market size

Kwh: Kilowatt-hour

$L$ : Labor input

LILCO: Long Island Lighting Company

log-log: Logarithm of the variables are applied in both sides of cost function

MCD: Minor civil divisions including cities, villages, and towns

mcf: volume of thousand cubic feet of natural gas

$\min C$ : Function that minimizes costs

NM: Niagara Mohawk Power Corporation

$N_{R}$ : Number of residential customers

NYS: State of New York

NYSDEA: New York State Division of Equalization and Assessment

OR: Orange and Rockland Utilities

$P$ : Vector of input prices

$p$ : Input price

$P_{\text {FUEL }}:$ Price of fuel

$Q$ : Vector of outputs, including sales and number of customers in different sectors.

$S_{C I}$ : Sales to commercial-industrial customers

$S H$ : Vector of socio-economic and site-specific characteristics

$S I T E=$ Vector of site-specific variables in that specific tax district

SOIL ${ }_{\text {CORR }}$ : Soil corrosivity

$S_{R}:$ Sales to residential customers

STATSGO: The State Soil Geographic Database of the U.S. Department of Agriculture

U.S.: United States

USGS: The United States Geological Survey

$W A T_{D E P T H}$ : Depth of water table

$Z$ : Customer size, which is ratio of sales to number of customers

$\theta$ : Box-Cox parameter for the dependent variable

$\lambda$ : Box-Cox parameter for the independent variables

\section{REFERENCES}

ALAEIFAR, M., FARSI, M., FILIPPINI M. (2014) Scale Economies and Optimal Size in the Swiss Gas Distribution Sector, Energy Policy (65) 86-93. 
American Society of Civil Engineers (2013) Report Card for America's Infrastructure, Energy. [http://www.infrastructurereportcard.org/ a/\#p/energy/overview] Accessed Date (24.11.2015).

BAUMOL, W.J., PANZAR, J.C., WILLIG. R.D. (1982) Contestable Markets and the Theory of Industry Structure, Harcourt Brace Jovanovich, New York.

BERNARD, J., BOLDUC, D., HARDY, A. (2002) The Costs of Natural Gas Distribution Pipelines: the case of SCGM, Quebec, Energy Economics (24) 425-38.

BOX, G.E.P., COX, D.R. (1964) An Analysis of Transformations, Journal of the Royal Statistical Society Series B 26(2) 211-52.

CHAMBERS, W.L. (1959) Engineering Soil Classification for Residential Developments, Federal Housing Administration, Washington D.C.

CHRISTIENSEN, L.R., GREENE, W.H. (1976) Economies of Scale in U.S. Electric Power Generation, The Journal of Political Economy 84(4) 65576.

CLAGGETT, E.T. (1994) A Cost Function Study of the Providers of TVA Power, Managerial and Decisions Economics 15(1) 63-72.

U.S. Energy Information Administration. (2012). Today in Energy November 1, 2012. [http://www.eia.gov/todayinenergy/detail. cfm?id=8590] Accessed Date (24.11.2015).

FABBRI, P., FRAQUELLI, G., GIANDRONE, R. (2000) Costs, Technology and Ownership of Gas Distribution in Italy, Managerial and Decision Economics (21) 71-81.

FILIPPINI, M. (1996) Economies of Scale and Utilization in the Swiss Electric Power Distribution Industry, Applied Economics (28) 543-50.

FILIPPINI, M. (1998) Are Municipal Electricity Distribution Utilities Natural Monopolies? Annals of Public and Cooperative Economics 69(2) 157-74.

FILIPPINI, M., WILD, J. (2001) Regional Differences in Electricity Distribution Costs and Their Consequences for Yardstick Regulation of Access Prices, Energy Economics (23) 477-88.

FOLLONI, G., CALDERA, O. (2001) Size, Density and Costs of Network Services - The Case of the Distribution of Electricity in Italy. European Regional Development Issues in the New Millennium and Their Impact in Economic Policy, 41st Congress of the European Regional Science Association (196) 1-17.

GULDMANN, J. (1983) Modeling the Structure of Gas Distribution Costs in Urban Areas, Regional Science and Urban Economics (13) 299-316.

GULDMANN, J. (1985a) A Disaggregate Econometric Analysis of Electricity Distribution Capital Costs, Energy (5) 601-12.

GULDMANN, J. (1985b) Economies of Scale and Natural Monopoly in Urban Utilities: The Case of Natural Gas Distribution, Geographical Analysis 17(4) 302-17.

GULDMANN, J. (1988) Land Use, Market Mix, and the Allocation of the Investment Costs of Electricity Distribution Networks, SocioEconomic Planning 22(5) 201-12. 
GULDMANN, J. (1989) Capacity Cost Allocation in the Provision of Urban Public Services: The Case of Gas Distribution, Growth and Change, 20(2) 1-18.

HENDERSON, S.J. (1985) Cost Estimation for Vertically Integrated Firms: The Case of Electricity, Analyzing the Impact of Regulatory Change in Public Utilities, ed. A.C. Michael, Lexington Books, Massachusetts; 75-94.

HUETTNER, D.A., LANDON, J.H. (1978) Electric Utilities: Scale Economies and Diseconomies, Southern Economic Journal 44(4) 883-912.

JAMASB, T., OREA, L., POLLITT, M. (2012) Estimating the Marginal Cost of Quality Improvements: The Case of the UK Electricity Distribution Companies, Energy Economics (34) 1498-506.

KASERMAN, D.L., MAYO, J.W. (1991) The Measurement of Vertical Economies and the Efficient Structure of the Electric Utility Industry, The Journal of Industrial Ecnomics 39(5) 483-502.

KIM, T., LEE, J. (1995) Cost Analysis of Gas Distribution Industry with Spatial Variables, Journal of Energy and Development 20(2) 247-67.

KWOKA, J.E. (1996) Power Structure: Ownership, Integration, and Competition in the U.S. Electricity Industry, Kluwer Academic Publishers, Boston.

KWOKA, J.E. (2002) Vertical Economies in Electric Power: Evidence on Integration and Its Alternatives, International Journal of Industrial Organization (20) 653-71.

MEYER, R.A. (1975) Publicly Owned versus Privately Owned Utilities: A Policy Choice, The Review of Economics and Statistics 57(4) 391-99.

NELSON, R.A., PRIMEAUX, W.J. (1988) The Effects of Competition on Transmission and Distribution Costs in the Municipal Electric Industry, Land Economics 64(4) 338-46.

NEMOTO, J., NAKANISHI, Y., MADONO, S. (1993) Scale Economies and Over-Capitalization in Japanese Electric Utilities, International Economic Review 34(2) 431-40.

NEUBERG, L.G. (1977) Two Issues in the Municipal Ownership of Electric Power Distribution Systems, The Bell Journal of Economics 8(1) 303-23.

PRIMEAUX, W.J. (1975) A Re-examination of the Monopoly Market Structure for Electric Utilities, Studies in the Regulation of Economic Activity: Promoting Competition in Regulated Markets, ed. A. Phillips, The Brookings Institution, Washington D.C.; 175-200.

ROBERTS, M.J. (1986) Economies of Density and Size in the Production and Delivery of Electric Power, Land Economics 62(4) 378-87.

SALVANES, K.G., TJOTTA, S. (1994) Productivity Differences in Multiple Output Industries: An Empirical Application to Electricity Distribution, The Journal of Productivity Analysis (5) 23-43.

SALVANES, K.G., TJOTTA, S. (1998) A Test for Natural Monopoly with Application to Norwegian Electricity Distribution, Review of Industrial Organization (13) 669-85.

THOMPSON, H.G. (1997) Cost Efficiency in Power Procurement and Delivery Service in the Electric Utility Industry, Land Economics 73(3) 287-96. 
WEISS, L.W. (1975) Antitrust in the Electric Power Industry, Studies in the Regulation of Economic Activity: Promoting Competition in Regulated Markets, ed. A. Phillips, The Brookings Institution, Washington D.C.; 135-73.

WELLS, F.J. (1977) The Effects of Customer Density on Electrical Distribution Costs, Local Service Pricing Policies and Their Effect on Urban Spatial Structure, ed. P.B. Downing, University of British Columbia Press, Vancouver; 87-118.

YATCHEW, A. (2000) Scale Economies in Electricity Distribution: A Semiparametric Analysis, Journal of Applied Econometrics (15) 187-210.

\section{GEOGRAPHY AND THE CAPITAL INVESTMENT COSTS OF URBAN ENERGY INFRASTRUCTURE: THE CASE OF ELECTRICITY AND NATURAL GAS NETWORKS}

Urban infrastructures are characterized by considerably high investment costs, which make investments almost irreversible. Once the construction is completed, it is difficult and expensive to modify the systems. Therefore a detailed cost analysis should be carried out in advance, to prevent unprecedented future charges and provide reliable infrastructure services. This study aims to reveal the economic characteristics of urban energy (electricity and natural gas) distribution systems' investment costs using (1) capital investment costs at the local level; (2) outputs such as sectoral numbers of customers and energy sales, and input prices; (3) companyspecific characteristics of energy distribution firms; and (4) socio-economic and site-specific urban and geographic variables. However, the fourth group variables have often been neglected in the literature, although the impacts of such variables are expected to be highly relevant. In this study, an econometric approach has been utilized for cost analysis. Regression models tested both log-log and the Box-Cox forms, while the Box-Cox regression model, as a flexible form allowing for the endogenous determination of the parameters, gave better results. Regression estimates show that besides the output and input variables, and company-specific variables, socio-economic and site-specific urban and geographic variables have statistically significant effects on electricity and natural gas distribution capital investment costs. Moreover the results provide evidence for economies of scale and density in these distribution systems under various configurations of market size and local conditions.

Alındı: 14.10.2015; Son Metin: 12.01.2016

Anahtar Sözcükler: Kentsel enerji altyapısl; elektrik dağıtım şebekesi; doğal gaz dağıtım şebekesi; altyapı maliyetleri; ölçek ve yoğunluk ekonomileri.

\section{KENTSEL ENERJI ALTYAPISININ COĞRAFİ ÖZELLİKLERİ VE SERMAYE YATIRIM MALIYETLERİ: ELEKTRİK VE DOĞAL GAZ ŞEBEKELERI ÜZERINE BİR ÇALIŞMA}

Kentsel altyapı oldukça yüksek maliyetlerle betimlenir ve bu durum, yatırımları neredeyse geri alınamaz kılar. Yapım tamamlandığında sistemlerde değişiklik yapmak oldukça zor ve masraflıdır. Bu nedenle, yatırım öncesinde ileride karşılaşılabilecek beklenmeyen maddi yüklerin önlenmesi ve güvenilir altyapı hizmetlerinin sağlanması için ayrıntılı bir maliyet çözümlemesi yapılmalıdır. Bu çalışma, kentsel enerji (elektrik ve 
doğal gaz) dağıtım sistemleri yatırım maliyetlerinin (1) yerel düzeyde sermaye yatırım maliyetleri; (2) sektörel kullanıcı sayısı ve enerji satış miktarları gibi çıktılar ile girdiler; (3) dağıtım şirketlerinin kendilerine özgü nitelikleri; ve (4) sosyo-ekonomik ve yerleşimlere özgü kentsel ve coğrafi değişkenler kullanılarak açıklanmasını amaçlamaktadır. $\mathrm{Ne}$ var ki literatürde, dördüncü grup değişkenlerinin etkilerinin oldukça anlamlı olması beklenmesine rağmen, bu değişkenler göz ardı edilmiştir. $\mathrm{Bu}$ çalışmada maliyet analizinde ekonometrik bir yaklaşım izlenmiştir. Regresyon modellerinde hem log-log hem de Box-Cox formları denenmiş ve parametrelerin içsel belirlenmesine izin veren esnek bir form olan BoxCox regresyon modelinin daha iyi sonuç verdiği görülmüş̧ür. Regresyon kestirimleri; girdi ve çıktı değiş̧kenleri ile şirkete özgü değişkenlerin yanı sıra, sosyo-ekonomik ve yerleşimlere özgü kentsel ve coğrafi değişkenlerin de elektrik ve doğalgaz dağıtım sistemleri sermaye yatırım maliyetlerine istatistiki olarak anlamlı etkileri olduğunu göstermektedir. Ayrıca sonuçlar, dağıtım sistemlerinde piyasa büyüklükleri ve yerel koşulların farklı şekillenmelerinde ölçek ekonomileri ve yoğunluk ekonomilerinin varlığına ilişkin de bulgular da sunmaktadır.

MÜZEYYEN ANIL ŞENYEL; B.CRP, MSc, Ph.D.

Received her bachelor's and master's degrees in city planning from Middle East Technical University (1999-2006). Obtained her MSc. and PhD degrees in City and Regional Planning from the Ohio State University (2007-2013). Currently works as an instructor at Middle East Technical University. Major research interests include quantitative methods in planning, urban infrastructure and sustainability. senyel@metu.edu.tr

JEAN-MICHEL GULDMANN; Ph.D.

Professor Emeritus at the Ohio State University, City and Regional Planning

Department. Taught courses on optimization, decision and forecasting techniques, energy and regional modeling; supervised $29 \mathrm{PhD}$ students; and published Industrial Location and Air Quality Control (John Wiley) as well as 76 articles, and 2 book chapters. guldmann.1@osu.edu 